\title{
Transformations and Permanences of landscape and architecture: the Minerva Tower of Punta Campanella in the Sorrento-Amalfi Peninsula
}

\author{
Stefania Pollone ${ }^{a}$, Lia Romano ${ }^{b}$
}

Università degli Studi di Napoli Federico II, Department of Architecture, Napoli. Italy, astefania.pollone2@unina.it,

blia.romano2@unina.it

\begin{abstract}
The Minerva Tower is placed on the Punta Campanella promontory, which is the last offshoot of the Sorrentine Peninsula and seat of suggestive archaeological and mythological memories. The strategic position contributed, over the centuries, to the settlement of important architectures, such as the sanctuary dedicated to Athena and a Roman domus, which makes the area a complex and rich palimpsest of material stratifications. The Minerva Tower - that nowadays is the main landmark of the promontory - was built in 1334 in relation to the site of the temple of Athena but was completely transformed in 1566, as a consequence of the strengthening plan of the southern coasts which was planned by the Spanish viceroy Pedro Afán de Ribera Duke of Alcalà. The paper deepens the knowledge of the tower by analyzing the transformations during the viceroyal period and highlighting the changes and the hidden ancient traces which are preserved until today.
\end{abstract}

Keywords: stratifications, viceroyal plan, cultural landscape, ancient infrastructure

\section{Introduction}

The landscape of the Sorrento-Amalfi Peninsula represents a meaningful example of coexistence of natural and human characters. For a palimpsest like this, the overlapping of archaeological, environmental, rural, historical and anthropic components - stratified during centuries - makes appropriate the definition of 'cultural landscape'. The western offshoot of the peninsula - watershed between the gulfs of Naples and Salerno - belongs to the Massa Lubrense Municipality. This territory, comprehensive of eighteen hamlets, with a coastline extended from Marina di Puolo to the hamlet of Torca for a length of about $20 \mathrm{~km}$, is characterized by an imposing dolomite limestone promontory, animated by cliffs, deep recesses and coves of different shapes and extensions (Bonghi Jovino, 2008). Despite that hostile orography, the strong presence of archaeological traces, of ancient and modern structures as well as the frequent recall to mythological memories testify the early anthropization of these lands and the continuity in their uses through the centuries. Linked to the religion, agriculture, fishing, breeding or to the defense of the sites, human activities had left clear imprints on the territory recognizable in material evidences and intangible traditions. In these lands «populated by ruins» (Pane, 1955) a dense network of footpaths, mule tracks and paved roads - with a linear extension that exceeds $100 \mathrm{~km}$ - becomes the link between the preexistences, testifying, at the same time, both in their ancient forms, as in their modern stratifications, the relation between permanences and transformations. 
Facing the island of Capri, Punta Campanella - a high chalky promontory overlooking the sea represents the extreme offshoot of the peninsula. Frequented at least from the 6th century B.C., as the archaeological remains testify, this area housed the temple of Athena already around 550 B.C., which survived without evident continuing solution until the Imperial Roman Age (Greco, 2014), when that place was called Promontorium Minervae and a terraced domus was built in proximity of the sanctuary. Reachable by the sea thanks to two natural landing-places and a steps cut out of the rock, and because of its proximity with Capri, Punta Campanella was probably used as landing and resting point for the Emperor Tiberius, or at least, for those who came from the island (Pane, 1955). According to this hypothesis, the continuity in the use of the structures of the point over the centuries ensured also their conservation and the preservation of the route - the so called via Minervia - that linked Punta Campanella with the inland. Clearly marked together with the temple of Athena in the Tabula Peutingeriana - a medieval copy of a Roman figured itinerary - this halfway up the hill path «visible from the sea to anyone who travels between Capri and Naples [...] is today little more than a mule path, yet it is worthy of being singled out as one of the most suggestive place of the classical world because of the landscape's beauty along its route and the presence, profiled between sea and sky, of the Greek cuts through the rock-face and the Roman paving stones» (Pane, 1955).

Starting from the Medieval Age and also during the Modern Age, facing the danger of raids of pirates and marauders, firstly, and of Saracen corsairs, later, those characters that have made strategic the position of Punta Campanella, turned into vulnerabilities. The presence of natural landings and of several coves just below the point, in fact, could offer safe landing and refuge to the raiders. For this reasons, starting from the Fourteenth century, this place became one of the principal stronghold of the coastal defensive system, confirming its role until the Twentieth century.

\section{The Minerva Tower and the coastal defensive system}

The first definition of a structure for the defense of the coasts nearby Punta Campanella dates back to the Angevin Age when, starting from 1290, Charles d'Anjou decided to begin the development of a plan of fortifications to protect the coastline from pirates. Between the end of the 1334 and the beginning of the 1335, Robert d'Anjou - to which is attributed the realization of more than 330 towers - ordered the construction of a tower «in loco qui dicitur Minerba» (Filangieri di Candida, 1910). Built by Marino Giracio from Vettica Maggiore (a little hamlet of Praiano) - who was appointed castellan for life the Minerva Tower had probably to be characterized, as other fourteenth-century Angevin military garrisons, by a slim cylindrical shape consisting of a well worked grey-tuff masonry (Ercolino, 1992). The tower, which according to some sources - in 1343, after ten years from its construction, during the reign of Charles III of Durazzo, had already been restored (Filangieri, 1910), was completely transformed starting from the second half of the Sixteenth century in order to be adapted to new defense needs.

During the Spanish Vicereign (1501-1707), in fact, the intensification of Saracen attacks and corsair raids from the coasts of North Africa and of the Eastern Mediterranean areas made necessary the improvement of the coastal fortifications. This measure, firstly undertaken by Charles V, was carried out by the viceroy Pedro de Toledo who defined a general plan to fortify the entire Neapolitan reign's coastline. The works began with the fortification of the Eastern side of the Vicereign, considered more vulnerable, and only after the Saracen disastrous attack that, in 1558, hit the Sorrentine Peninsula and, particularly, the city of Massa Lubrense, measures for the protection of the western coasts appeared to be more urgent. Unlike the Aragonese plan according to which the towers had to sigh and signal threats from the sea through a triangulation system, the viceroyal plan, conducted from 1563 by Pedro Afán de Ribera Duke of Alcalà, envisaged the definition of a new type of fortified towers equipped with 
eavy artillery so as to be able to counterattack as well as sign and signal danger. The first order of construction of a tower on Punta Campanella dates back to 1564 , but the sources report that the Minerva Tower was «rebuilt» in 1566 and, together with it, were built other eight towers on Massa Cape, St. Lawrence Cape, Vaccola Point, Fossa Papa, Mortella Point, Marina del Cantone, Recommone and Crapolla (Filangieri, 1910; Santoro, 1967) in order to defend the most vulnerable points of the coastline. As in other cases, the preexistent fourteenth-century cylindrical tower, not suited to resist to the shots of the naval cannons and to contain the 'modern' eavy artillery, was probabily abandoned and the new tower built in correspondence of the upper terrace in a more defensible position. According to some hypothesis, the circular profile of the area below the viceroyal tower could be assimilated to the base of the medieval one, as well as, several grey-tuff blocks, originally belonging to this latter, would be recognizable in the masonry of the new structure (Ercolino, 1992). In support of the hypothesis regarding the spatial arrangement of the two towers, we could consider the case of the tower of Cetara whose volumetry testifies still today the coexistence of an adapted medieval tower with an upper viceroyal one.

Despite the structure of Minerva Tower has undergone, during centuries, several trasformations which have compromised the sixteenth-century volumetry, the direct interpretation of the material evidences, and the comparison with other better preserved similar structures (as the tower of St. Peter in Crapolla), together with the study of the indirect sources, allow to interpret its original configuration. The structure of Punta Campanella corresponded to the building scheme of the viceroyal towers. In visual connection with the nearby towers of Fossa Papa and Montalto, the Minerva one was characterized by a frusto-pyramidal shape with sloping profiles - suited to resist to the shots of naval cannons and to absorb the dynamic strain resulting from their own artillery - and a counterscarp crowing consisting of a system of five spatula machicolations (troniere a spatola) (Santoro, 2000; Russo, 2009). The tower - whose massive limestone masonry was thicker in correspondence of the front towards the sea had three floors comprehensive of a first level for food and munitions storage and a cistern, a second one for the accommodation of the soldiers - reachable from an external step staircase - and an upper parade ground with a sentry box (no more readable today). The large barrel vaults were mutually perpendicular in order to ensure a high rigidity and a considerable resistance. The orientation of the plan, the noteworthy dimensions and the presence of five machicolations - characteristics punctually determined by viceroyal military engineers in function of the vulnerability of the site and of the necessary armament - testify the fundamental role of that structure in the plan of coastal defense (Santoro, 2000; Russo, 2009).

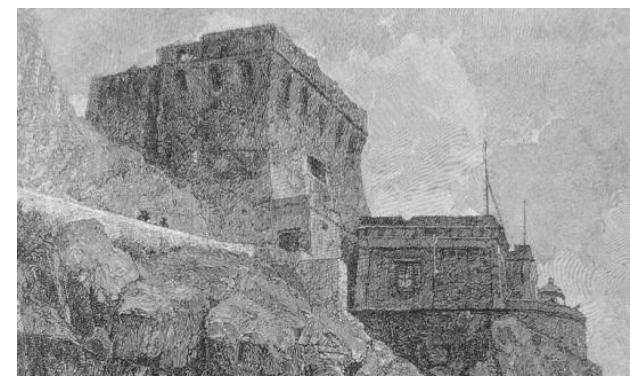

Fig. 1- Die Punta della Campanella gegenuber Capri. Engraving from a painting of Karl Böhme, about 1880, detail (Bonghi Jovino, 2008)

Despite the scarcity of precise archival or bibliographical references, it is possible to outline an evolution of the transformations of Minerva Tower until the Nineteenth century even through the interpretation of iconographical and photographical sources. An important testimony of a seventeenth-century phase of transformation of the originally viceroyal plant is recognizable in the views of Capri (1698, 1703) by Cassiano de Silva. Framing with the island also Punta Campanella, the artist punctually described the tower by delineating its significant characters. The presence of a onefloor structure clearly represented in correspondence of the upstream front of the tower, lets us assume that this simple architecture (nowadays still visible although modified) was realized already during the 
seventeenth-century - in contrast to the opinions that consider it as a nineteenth-century addition (Ercolino, 1992) -, probably in order to enlarge the original plant or to protect the entrance.

During the French Decade, several coastal defense garrisons of the Massa Lubrense territory were fortified because of the presence of the English army on the nearby island of Capri and were included in the Command of the left side of the Gulf (Santoro 2000; Russo, 2001; Amirante, 2008). As well in the case of Corvo Cape in which the restoration of the viceroyal tower to allocate munitions storage and soldiers' accommodation and the construction of a battery on the sea level to host the cannons were carried out (Amirante, 2008), also Punta Campanella had a role in the coastal defense. Regarding the project of adaptation of Minerva Tower, from a document attributed to General Franceschi we can read: «located at about thirty meters above the sea level, it is not able to accommodate artillery but only $26-30$ men of the $20^{\text {th }}$ Infantry. The tower appears to be too advanced and exposed; its first and second floors must be used as deposits, the third one as parade ground. Being the vaults not too much solid it is discouraged to install cannons on it. For that purpose the lateral square seems adequate to accommodate a battery of three pieces and a mortar» (Santoro 2000). This description provides interesting information about the bad state of conservation of the vaulted structures of the tower, and, since the interiors of this latter were used as deposits, seems to confirm the hypothesis of the preexistence of the one-floor buildings placed against the tower probably used to accommodate that large number of soldiers.

During the Bourbon Restoration, according to a policy of continuity with the French military choices, a Commission was appointed with the aim of determining which batteries needed to be conserved, abolished or built. In a first phase, in 1815, the battery built on Punta Campanella, considered useless, was disarmed (Santoro 2000; Russo, 2001). Then, after an inspection carried out by the Captain Domenico Colella during 1828 in order to identify the state of conservation and the potential usefulness of the Tyrrhenian batteries, the structure of the point, considered indispensable to defend the Straits, was classified as a battery to be conserved, specifying its good state of conservation and that was not needed any repair (Sirago, 2008).

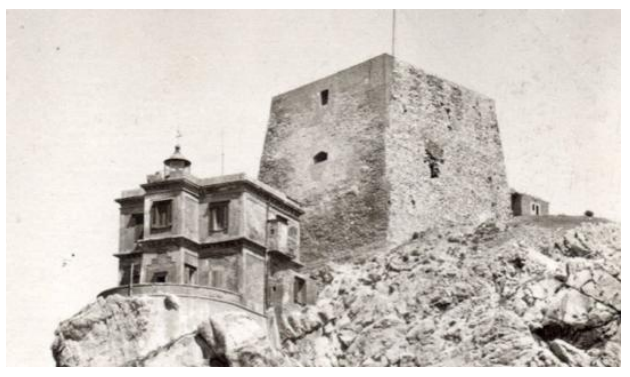

Fig. 2- Minerva Tower during the Twenties of the 20th century (private collection)

The project for the construction of the lighthouse and of the keeper's house, realized on the terrace below the tower, dates back to the 1850 . In that period we could assume that the configuration of the tower had remained almost unchanged with respect to the sixteenth-century plant and the seventeenth-century addictions. To confirm this hypothesis it could be taken into account the engraving from a painting of Karl Böhme, dated back to 1880. Framing the high cliff and the complex consisting of the tower and the modern lighthouse' structures from the sea, the work clearly describes each details underlining the crowing of the tower still characterized by the five machicolations. From the comparison between this engraving and a picture dating back to the Twenties of the 20th century, it is possible to note evident differences: in correspondence of the crowing, both the sentry box as the machicolations are no more readable except, for these latter, some traces on the east front, while on the southern one wide tuff integrations and changes of the openings are visible. Taking into account the temporal interval between the two sources, it is reasonable to assume that a large part of the alterations were carried out during the first decades of the Twentieth century and, more probably, after the World War I.

During the last century the tower has undergone several modifications - sometimes rather invasive - which have made more difficult a clear comprehension of the structure. Occupied 
by the soldiers during the World War II and damaged by a huge fire that destroyed the lighthouse at the end of Sixties, the Minerva Tower has been the object, during the first half of the Nineteenth, of a series of interventions for its strengthening. These works have interested both the vertical masonries as the vaults which have been stiffened through an extensive use of armed consolidating injections and armed counter-vaults. Moreover, on the external façades, the corners have been totally rebuilt using a masonry similar to the ancient one, determining a complete alteration of the legibility of the palimpsest.

\section{Tower's permanences and transformations. The architectural layout}

Nowadays the lack of maintenance and the advanced state of decay of the building reveal a monument without some crucial features of the Viceroyal model such as the machicolations and the sentry box placed in the parade ground. As pointed out in previous paragraphs it is unknown the exact date of collapse or possible demolition of these structures, but some iconographical documents inform us that at the end of the 19th century the tower still had these systems, which were probably removed in the first decades of the 20th century. The presence of the traces of five identifiable machicolations - that were constituted by six oblique barbicans at the crowning and five slits for the cannons - testify the military importance of the Tower and its role as first-order stronghold.

Despite several interventions - not always documented - on the Minerva Tower throughout the centuries, the architectural layout and the interiors are still clearly comprehensible. The tower, built in limestone, extracted and split on site, has a truncated pyramid shape (sloping profile), that is planned in order to not constitute an easy target for ship cannons and to hold out against external attacks together with the strain caused by their own artillery.

The entrance to the building - which has a square plan approximate of fourteen meters dimension at the top - is at the centre of the northern façade, in front of the hill, and has been made possible by a partially collapsed staircase in the masonry. It is part of a structure, in ruins, which is placed against the 16th century tower, very stratified and made up of three uncovered rooms.

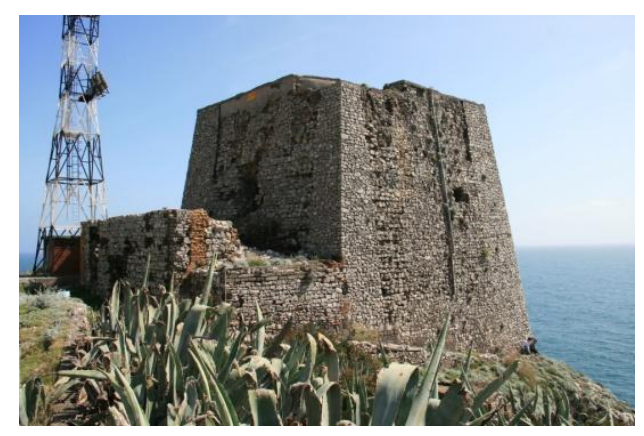

Fig. 3- Minerva Tower. The added structure on the northern side (2015)

The tower stands on three floors which are covered by barrel vaults. They are built in orthogonal way in order to share homogeneously the loads to the four sides of the building. The intermediate floor is planned as a lodging for the soldiers and guards and has several windows, among which the main are in the north-east and south-west side of the tower and were used to watch over the coastline and to communicate with Fossa Papa and Montalto Towers. Usually, the Viceroyal Towers had blind walls facing seawards, but in the case of Punta Campanella we can identify two openings in the south side, placed on the same axis but with different features. The lower opening, probably the oldest one, is splayed and obtained in a quite big round arch; it has a quadrangular shape inside and an arch shape outside. The other opening, which is rectangular and splayed, is placed above, on the same axis of the other one and was probably realized after the demolitions of the machicolations because it occupies the same area which earlier was earmarked to them. The embrasure upwards, moreover, does not allow to check the sea and the ships but the sky and, so, it could be realized and used because of military aims during the World War II. The space used as lodging has a lot of recesses - which are cut out in the wall thickness - a chimney for smoke signals with a furnace, a probable sink and a 
little building placed against the masonry used for taking meteoric water from the underlying cistern.

The lodging is connected to the lower floor by a staircase made by masonry. It is used as a pantry and in communication with a little storage and a cistern in a good state of conservation and covered by cocciopesto. The underground floor's structure is unusual and related to the dimensions of the building. In other cases - for example in St. Peter Tower at Crapolla, with three machicolations, the basement is used only as a cistern and there are not other spaces. In the tower with five machicolations, as Punta Campanella Tower, instead, the spaces in the lower floor are organized in a cistern, a pantry which is provided with splayed openings used to enlighten and to air - and a little storage (Russo, 2001). Probably, because of its defensive role, the Tower is equipped to host a lot of soldiers and to keep food and artillery.

The rainwater arrives in the cistern through a drainage system. The water - which was collected in the covering thanks to a network of inclines and reservoirs - leads into pipes cut out in the masonry thickness. Nowadays the cistern is not used and the rainwater is directed into a pluvial - placed in the south-west side of the tower - which formerly canalized part of the water into a little tank, probably used as drinking trough. The parade ground - which is accessible by a narrow staircase cut out in the wall's inner thickness - was originally covered by lapillus and crushed lime. This traditional technique allowed to realize a protective layer to improve the structural behaviour of the building. Indeed, palls of lime mortar, hydrolyzed by adding lapillus, were beaten for some days by increasing the mutual contrast among the vaults' stone ashlars and by producing, indirectly, a stiffening of the structure. The reinforcements, which were carried out during the 1990s, provided for the removal of lapillus because of its advanced decay and the realization of a waterproof layer in asphalt. This last one does not allow a correct transpiration of the masonry and causes a structural weakening of the underlying vault, which is collapsed in the central part. During the 20th century, moreover, a stringcourse in concrete was realized. Today its iron rods are oxidized and in advanced state of decay such as the asphalt that is strongly cracked and invaded by the local vegetation, the Centaurea (centaurea cineraria), that is a typical flora of the Mediterranean scrubland (Ricciardi, 1992). This plant - which is widespread especially in rocky areas - grows in the limestone, that is the same material of Minerva Tower, by highlighting the strong connection existing in these places between architecture and nature.

\subsection{Building materials and techniques}

The advanced state of decay of Minerva Tower allows to carry out a good interpretation of the structures because the plaster is almost disappeared both in the internal and in the external facing. It is legible - in spite of the loss of a large amount of limestone and the addition of other materials - the Viceroyal constructive technique so-called 'a cantieri'. It was regulated by a pragmatic sanction which was issued by the Viceroy Pedro Afán de Ribera in 1564 and represented the benchmark for the building activity up to the Ferdinand IV Bourbon' edict in 1781 (Russo, 1999).

According to this technique, the realization of the building takes place stage-by-stage and is articulated in 'cantieri' (yards), which are conceived en bloc without significant distinctions between the internal and the external facings. The yard's dimension is about $35-65 \mathrm{~cm}$ and is made up ashlars, which are put together without attention for the horizontal and vertical staggering of the joints. The yards are realized, through opus incertum, which is characterized by irregular ashlars and mortar with limestone and other aggregates such as clay.

The passage from a yard to another is highlighted by balancing little materials and by a double layer of mortar. This last one is realized by fresh water (the sea water was forbidden by law), lime - extracted by local lime kilns - and various aggregates such as yellow and grey tuff, limestone, clay, and lumps of lime-off. The presence of this last material testifies that the 
construction was done in a short time. The internal plaster, of which some traces are preserved, is realized with lime, water and fragments of lapillus, a little volcanic aggregate coming from areas of the Campania near to Vesuvius. This material was used in order to improve the water and humidity resistance of the protection layers, that is the plaster. It is unknown, like in the case of St. Peter's Tower at Crapolla, the position of the lime kiln used for the extraction of the limestone necessary for the construction of the building and the realization of the mortar, but it was probably situated near the building site because of logical difficulties.

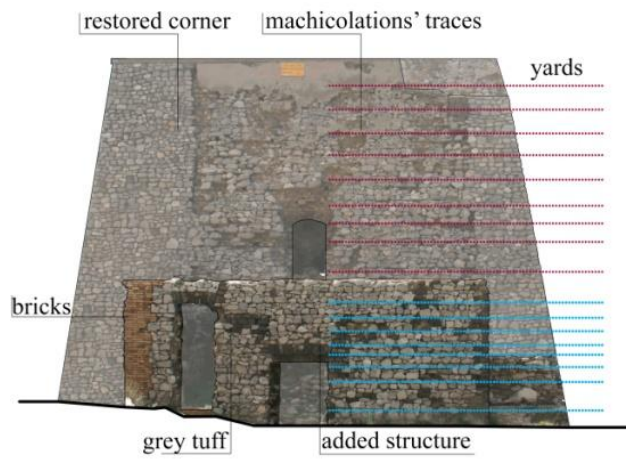

Fig. 4- Minerva Tower, the northern facade

In the Minerva Tower at Punta Campanella the yard dimension on the external facing is not simply recognizable due to the strong decay and the interventions carried out over the centuries. The last in chronological order is the restoration carried out in 1990s which provided for the complete reconstruction of the corners by deleting, in this way, the possibility to read the masonry structure and, above all, the passages from a yard to another one. However, thanks to direct inspection and the comparison with the internal facing, it was possible identify masonry courses between 80 and $100 \mathrm{~cm}$ high, that is about three/four Neapolitan Palms, the unit of measurement used in the Viceroyal period. It is not possible to observe, such as in other towers, a significant increase of the yards in line with the vaults' curving and a decrease in correspondence to the machicolations. In the basement, instead, by analyzing the interior facing of the pantry, the yards' height is shorter (about $52 \mathrm{~cm}$ that are two Neapolitan Palms). The reason of these variations can be explained taking into account the greater dimension of the masonry thickness at the basement of the Tower and the reduction at the top of the truncatedpyramid building. The ashlars' size are variable but in the pantry and in the cistern are more regular and $20 \mathrm{cms}$ high, by forming a yard through two 'rows'. In the lodging, instead, the masonry weaving is irregular and the limestone ashlars are bigger and executed with various aggregates together to additions in brick.

The modifications carried out over the centuries and the current decay allows to do a scaffolding holes' interpretation and analysis only partial and incomplete. According to the established practice of that period and by the analysis of a few observed holes, it is possible to assume that scaffolding holes could be repeated horizontally every two yards (and so every four Neapolitan Palms) and vertically about every three meters. Their close sequence is justified by the considerable masonry thickness, which at the basement measures about 4 meters and at the crowning 2.4 meters.

By analyzing the facing wall, especially the external ones, additions of various materials such as grey tuff of Sorrento, yellow tuff and bricks are recognizable. In particular the southern crowning of Minerva Tower overlooking the sea - is made up of quadrangular ashlars in yellow tuff, which was probably implemented following the demolition of the machicolations and the opening of the new window.

The integrations of the corners and the lintels in the structure which is placed against the tower in the northern side, instead, are very different. In this case, the ashlars are more short and wide, and are built without particular attention for the vertical staggering of the mortar joints. These additions are placed side by side to others which are realized in bricks and concrete mortar and are part of a more ancient wall. This one is made up of limestone through the use of the 'yard' technique. In this case, however, the limited dimensions, about $30 \mathrm{cms}$, suggests that the structure could be built in a transition stage 
between the yard and the 'filari' (rows) technique, which develops in the last decades of the XVIII century. The several stratifications of this masonry and the particular plan of the structure - that is not a peculiar feature of the Viceroyal model Tower - constitute open questions which should be susceptible of new studies and analysis.

\section{Conclusions}

The historical and stratigraphic interpretation carried out on the Minerva Tower at Punta
Campanella represents an important study for the improvement of knowledge about a building which is particularly interesting in terms of both its landscape and its architectural qualities. The knowledge process which has begun through this work - that is in progress and open to in-depth analyzes - constitutes an indispensable work in order to elaborate a project of conservation, aware of the values of the historical architecture and a following enhancement plan which could be able to not modify and alter a consolidated landscape habitat.

\section{References}

Amirante G. (2008), La dorsale difensiva napoletana e le fortificazionei alla 'sinistra' e alla 'dritta' del golfo. In Amirante G., Pessolano M.R. coord. (2008). pp. 51-90.

Amirante G., Pessolano M.R. coord. (2008), Territorio, fortificazioni, città. Difese del Regno di Napoli e della sua capitale in età borbonica, Edizioni Scientifiche Italiane, Napoli.

Archeoclub d'Italia - Massa Lubrense. coord. (1992), I Beni Culturali di Massa Lubrense. Contributo alla conoscenza, Eidos Ed., Castellammare di Stabia.

Bonghi Jovino M. (2008), Mitici approdi e paesaggi culturali. La Penisola Sorrentina prima di Roma, Nicola Longobardi Ed., Castellammare di Stabia.

Ercolino R. (1992). Il Sistema difensivo medievale in Massa Lubrense. In Archeoclub of Italy - Massa Lubrense. Coord. (1992), pp. 71-86.

Filangieri di Candida R. (1910), Storia di Massa Lubrense, Pierro Ed., Napoli.

Greco G. (2014). Peoples in the Sorrentine Peninsula, between myth and reality. In Russo V. coord. (2014). Landscape as Architecture. Identity and Conservation of Crapolla Cultural Site, Nardini Ed., Firenze, pp. 211-222.

Ricciardi M. (1992), Lineamenti essenziali del popolamento vegetale a Punta Campanella, in Archeoclub of Italy - Massa Lubrense Coord., pp. 99-108.

Russo F. (2001), Le torri anticorsare vicereali:con particolare riferimento a quelle della costa campana, Istituto Italiano dei Castelli - Sezione Campania Ed., Piedimonte Matese.

Russo F. (2009), Le torri costiere del Regno di Napoli. La frontiera marittima e le incursioni corsare tra il XVI ed il XIX secolo, Edizioni Scientifiche e Artistiche, Napoli.

Russo M. (1999), Magisteri murari "a cantieri" nell'età del viceregno spagnolo, in Fiengo G., Guerriero L, Murature tradizionali napoletane: cronologia dei paramenti tra il XVI e il XIX secolo. Arte tipografica Ed., Napoli, pp. 71-152.

Pane R. (1955), Sorrento e la costa, Edizioni Scientifiche Italiane, Napoli.

Santoro L. (1967), "Le torri costiere della Campania" in Napoli nobilissima, Arte Tipografica Ed., Napoli, pp. 38-49.

Santoro L. (2000), "Torri in costiera da Rovigliano a Vietri” in Apollo, Electa Napoli Ed., Napoli, pp. 17-114.

Sirago M. (2008), Città di mare e trasformazioni nell'assetto difensivo tra '700 e '800 in Amirante G., Pessolano M.R. coord., pp. 239-257. 